\title{
How to build segregation complexes in bacteria: Use bridges
}

\author{
Barbara E. Funnell ${ }^{1}$ \\ Department of Molecular Genetics, University of Toronto, Toronto, Ontario M5S 1A8, Canada
}

In this issue of Genes \& Development, Graham and colleagues (pp. 1228-1238) examine how ParBs, which bind to prokaryotic centromere-like partition sites, spread into nearby nonspecific DNA and assemble into higher-order protein-DNA complexes. Spreading is accomplished by looping rather than one-dimensional filamentation, thereby compacting the DNA into an extensively bridged complex.

Chromosome stability in bacterial cells requires the action of partition systems, which contribute to the accurate segregation of both cellular chromosomes and low-copy-number plasmids. Partition is essentially a transport mechanism for DNA, with plasmids or chromosomal domains as the cargo. Partition systems typically consist of two proteins that act on a centromere-like partition site, and the ParABS family, encoded by most bacterial genomes and many plasmids, is one of the most common in the microbial world. ParB is a site-specific DNA-binding protein that recognizes the partition site, called parS, and ParA is an ATPase whose activities drive localization of ParB/parS complexes. For a plasmid, this results in separation and transport of copies to opposite sides of the dividing cell. For a bacterial chromosome, the ParABS partition is thought to reposition and help organize the origin region, which typically contains most or all of several parS sites in the genome.

ParBs bind to parS sites and then "spread" to nearby nonspecific DNA to form large protein-DNA complexes that are visualized as fluorescent foci in vivo by cell imaging techniques. Bacterial ParBs also recruit host condensin or structural maintenance of chromosomes (SMC) proteins, and both are essential for efficient chromosome segregation. In the study by the Loparo and Rudner laboratories in this issue of Genes \& Development, Graham et al. (2014) examine how the ParBs assemble on DNA. Studying Bacillus subtilis ParB, called SpoOJ, they demonstrate that spreading occurs by bridging and looping DNA,

[Keywords: ParB; Spo0]; single-molecule fluorescence; bacterial chromosome segregation]

${ }^{1}$ Correspondence

E-mail b.funnell@utoronto.ca

Article is online at http://www.genesdev.org/cgi/doi/10.1101/gad.244517.114. which are necessary to form higher-order ParB/parS complexes and recruit SMC proteins.

Bacterial ParBs, including Spo0J, and those of many plasmids are dimeric helix-turn-helix (HTH) DNA-binding proteins, and pars sites contain inverted repeats to which they bind. ParBs bind nonspecifically to the DNA surrounding parS sites, a phenomenon known as spreading. Spreading was originally described in plasmid systems as an activity that could silence genes near parS (Lynch and Wang 1995; Rodionov et al. 1999). When ParB levels were artificially elevated, silencing extended many kilobases away from parS. Chromatin immunoprecipitation (ChIP) techniques detected peaks of ParB at parS sites but with significant additional binding that spread into the surrounding DNA sequence. Spreading was sensitive to "roadblocks," which were created by inserting strong DNA-binding sites for other proteins in the path of ParB. These observations led to the idea that ParB spread via lateral oligomerization; that is, as a one-dimensional filament along the DNA (Fig. 1). The oligomerization and spreading functions of ParBs mapped to an N-terminal region distinct from the HTH-specific binding motif (Kim and Wang 1999; Rodionov et al. 1999). The silencing turned out to be unimportant for partition (Rodionov and Yarmolinsky 2004), but the spreading ability was necessary to load multiple ParBs around parS, forming a higherorder partition complex.

Spreading is a common feature of the HTH class of plasmid and bacterial ParBs (Bingle et al. 2005; Murray et al. 2006; Breier and Grossman 2007). Although the filament model has been simple and attractive, the molecular nature of spreading has not been easy to examine directly, primarily because of the size of the complexes and because ParB interactions with nonspecific DNA are relatively weak. The Loparo and Rudner laboratories (Graham et al. 2014) have combined singlemolecule fluorescence imaging in vitro with sensitive cell imaging techniques in vivo to examine spreading and relate this DNA-binding activity to biological phenotypes. The first clue that a mechanism other than filamen-

(C) 2014 Funnell This article is distributed exclusively by Cold Spring Harbor Laboratory Press for the first six months after the full-issue publication date (see http://genesdev.cshlp.org/site/misc/terms.xhtml). After six months, it is available under a Creative Commons License (Attribution-NonCommercial 4.0 International), as described at http:// creativecommons.org/licenses/by-nc/4.0/. 


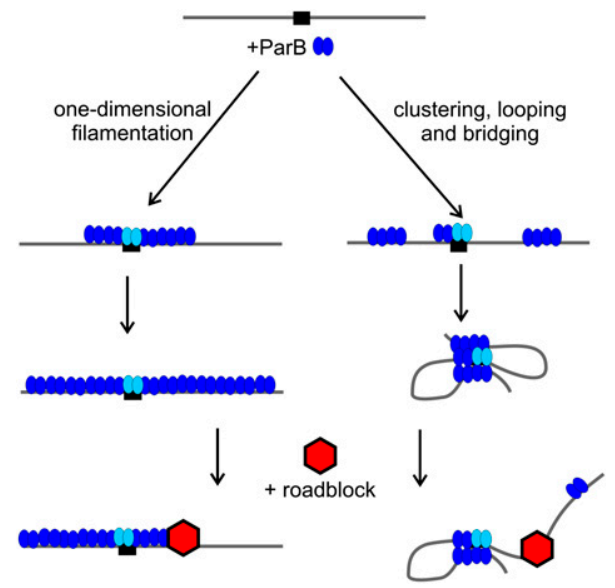

Figure 1. Two models for ParB spreading. On the left, ParB dimers (blue) form filaments in one dimension away from pars (black box). A roadblock, a strong protein-DNA complex (red), directly impedes the directional growth of the filament. On the right, ParB forms clusters by nearest-neighbor interactions and then bridges across loops to compact and condense the DNA molecule as well as bridge across DNA molecules. The presence of a roadblock interferes with loop formation or flexibility so that spreading is favored primarily in the opposite direction. Evidence from Graham et al. (2014) supports the right, bridging, mechanism. The light-blue ParBs are bound specifically to parS and presumably anchor the bridging so that loop formation is most stable when initiated at pars.

tation might be in play came from estimates of the number of SpoOJ molecules in a $B$. subtilis cell that indicate that there is not nearly enough protein to continuously cover the lengths of DNA bound by SpoOJ as measured by ChIP.

Graham et al. (2014) used total internal reflection fluorescence (TIRF) microscopy to dissect the nature of the nonspecific DNA-binding activity of Spo0J. In this setup, phage $\lambda$ DNA molecules $(\sim 50 \mathrm{~kb})$ were tethered at one end to a microscope slide. Force was applied by buffer flow, which extended the molecules in the direction of the flow. When SpoOJ was added, the DNA quickly compacted into a focus. To improve resolution along the DNA molecule, it was labeled at five loci with quantum dots (conjugated to catalytically inactive EcoRI). Using this "DNA motion capture," the compaction started from the free end of the DNA, essentially rolling up or condensing toward the tethered end. The end bias reflects the property that the tension or drag from the flow is highest at the tethered end of the DNA molecule. The free end is subjected to the least drag and thus has the most flexibility so that cooperative interactions across intracellular DNA loops will be most favorable and initiate there. Importantly, the investigators compared Spo0J behavior with that of two nucleoid-binding proteins: one that bridges DNA and one that does not. Escherichia coli HNS is a bridging protein and showed a similar end bias in the TIRF experiments. HBsu (B. subtilis HU) bends DNA but does not bridge and compacted the $\lambda$ DNA uniformly along its length. These elegant experiments (and the associated quantification of rates and concentration dependence) provide convincing evidence that spreading is essentially a bridging and looping activity, as ParB interacts with DNA across two and three dimensions as well as one (Fig. 1).

To correlate biology with biochemistry, Graham et al. (2014) identified several mutations in Spo0J that eliminate bridging in vitro and Spo0J focus formation in vivo. For the most part, these map to a small, well-conserved region of ParB, which they called Box II. Box II is a short, arginine-rich patch of residues in the $\mathrm{N}$-terminal half of ParB and is distinct from the HTH DNA-binding domain. However, one mutation in this region, G77S, previously identified as defective for spreading and focus formation in vivo (Breier and Grossman 2007), was still able to compact DNA as measured by TIRF (Graham et al. 2014). Therefore, bridging is necessary but not sufficient for the assembly of large ParB/parS complexes in vivo. Spo0J proteins with Box II mutations were also defective in recruitment of SMC complexes. The investigators proposed that SMC complexes are recruited to the DNA topology that is created by Spo0J bridging rather than (or in addition tol direct protein-protein interactions between Spo0J and SMCs.

\section{Bridging and higher-order partition complex assembly at parS sites}

DNA bridging is likely to be a general property of the HTH class of ParB proteins. Graham et al. (2014) showed the same bridging activity in TIRF assays for three other bacterial ParBs (Streptococcus pneumonia, Pseudomonas aeruginosa, and Vibrio cholera) and one plasmid ParB (P1). Indeed, although the overall sequence similarity among plasmid and bacterial ParBs is low, they all contain an arginine-rich patch in the $\mathrm{N}$-terminal half of the protein. The region has been implicated previously in spreading activity in other ParBs; for example, a mutation in Box II in P1 plasmid ParB is defective for its spreading, silencing, and partition activities in vivo (Rodionov et al. 1999).

The demonstration of bridging activity is an important advance, yet there are still gaps in our understanding of ParB/parS complex assembly. Graham et al. (2014) speculate that nearest-neighbor interactions between ParBs may be necessary to create patches or clusters of protein on DNA that then interact across strands to stabilize the loops and bridges (Fig. 1). The residues involved in and requirements for nearest-neighbor interactions have not been identified. How the arginine-rich Box II motif creates a bridge with a partner ParB molecule awaits structural definition. In vivo, the extensive spreading activity of ParB depends on nucleation at parS sites by its site-specific DNA-binding activity. The latter was not observed by TIRF even when parS was present on tethered $\lambda$ DNA, so we still do not understand how the nucleation event focuses ParB spreading around parS. Presumably, the strong ParB/parS interaction is necessary to stabilize bridges with ParB bound elsewhere.

Bridging activity may also occur at the pars site itself via the HTH-binding domains. Crystal structures of two plasmid ParBs bound to their partition sites imply that individual ParB dimers contact inverted repeats across 
parS sites (Schumacher and Funnell 2005; Schumacher et al. 2010). This activity might contribute to the observation that $B$. subtilis chromosomes with eight parS sites have fewer Spo0J foci at the origin than chromosomes with only four or two parS sites (Graham et al. 2014). In any case, the combination of specific Spo0J/parS binding, the bridging activity of SpoOJ, and the subsequent recruitment of SMC condensin complexes serves to condense the origin region of the chromosome into a compact domain.

\section{ParB/parS architecture and interactions with ParAs}

The HTH ParBs that form bridged complexes work in conjunction with a class of ParA ATPases that is defined by a specific variant of the Walker ATP-binding motif and likely by a common mechanism of action. These ParAs transport their DNA cargo over the surface of the bacterial nucleoid in an ATP-dependent patterning reaction, which requires dynamic interactions with $\mathrm{ParB} /$ parS complexes (Hwang et al. 2013). The molecular details of this mechanism are still being elucidated, but the requirement for large, compact, ParB/parS complexes is one way to present a high local concentration of ParB to ParA that is bound to the nucleoid. The presence of many dynamic ParB-ParA attachments is an attractive way to maintain association of ParB/parS complexes with ParA but simultaneously allow movement over the nucleoid surface.

\section{Acknowledgments}

I thank Jamie Baxter and Bill Waples for reading this perspective. This work was supported by Canadian Institutes of Health Research grant 133613.

\section{References}

Bingle LEH, Macartney DP, Fantozzi A, Manzoor SE, Thomas CM. 2005. Flexibility in repression and cooperativity by KorB of broad host range IncP-1 plasmid RK2. I Mol Biol 349: 302-316.

Breier AM, Grossman AD. 2007. Whole-genome analysis of the chromosome partitioning and sporulation protein Spo0J (ParB) reveals spreading and origin-distal sites on the Bacillus subtilis chromosome. Mol Microbiol 64: 703-718.

Graham TGW, Wang X, Song D, Etson CM, van Oijen AM, Rudner DZ, Loparo JJ. 2014. ParB spreading requires DNA bridging. Genes Dev (this issue). doi: 10.1101/gad.242206.114.

Hwang LC, Vecchiarelli AG, Han Y-W, Mizuuchi M, Harada Y, Funnell BE, Mizuuchi K. 2013. ParA-mediated plasmid partition driven by protein pattern self-organization. $E M B O$ J 32: 1238-1249.

Kim S-K, Wang JC. 1999. Gene silencing via protein-mediated subcellular localization of DNA. Proc Natl Acad Sci 96: 8557-8561.

Lynch AS, Wang JC. 1995. SopB protein-meditated silencing of genes linked to the sopC locus of Escherichia coli F plasmid. Proc Natl Acad Sci 92: 1896-1900.

Murray H, Ferreira H, Errington J. 2006. The bacterial chromosome segregation protein Spo0J spreads along DNA from parS nucleation sites. Mol Microbiol 61: 1352-1361.

Rodionov O, Yarmolinsky M. 2004. Plasmid partitioning and the spreading of P1 partition protein ParB. Mol Microbiol 52: 1215-1223.
Rodionov O, Lobocka M, Yarmolinsky M. 1999. Silencing of genes flanking the P1 plasmid centromere. Science 283: 546549.

Schumacher MA, Funnell BE. 2005. ParB-DNA structures reveal DNA-binding mechanism of partition complex formation. Nature 438: 516-519.

Schumacher MA, Piro KM, Xu WJ. 2010. Insight into F plasmid DNA segregation revealed by structures of SopB and SopBDNA complexes. Nucleic Acids Res 38: 4514-4526. 


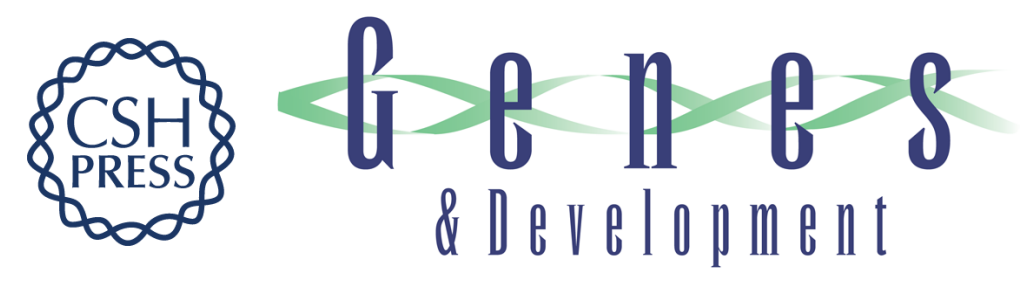

\title{
How to build segregation complexes in bacteria: Use bridges
}

\author{
Barbara E. Funnell
}

Genes Dev. 2014, 28:

Access the most recent version at doi:10.1101/gad.244517.114

\section{Related Content ParB spreading requires DNA bridging}

Thomas G.W. Graham, Xindan Wang, Dan Song, et al.

Genes Dev. June , 2014 28: 1228-1238

References This article cites 10 articles, 4 of which can be accessed free at:

http://genesdev.cshlp.org/content/28/11/1140.full.html\#ref-list-1

Articles cited in:

http://genesdev.cshlp.org/content/28/11/1140.full.html\#related-urls

Creative This article is distributed exclusively by Cold Spring Harbor Laboratory Press for the first

Commons

License

six months after the full-issue publication date (see

http://genesdev.cshlp.org/site/misc/terms.xhtml). After six months, it is available under a Creative Commons License (Attribution-NonCommercial 4.0 International), as described at http://creativecommons.org/licenses/by-nc/4.0/.

Email Alerting Receive free email alerts when new articles cite this article - sign up in the box at the top Service right corner of the article or click here.

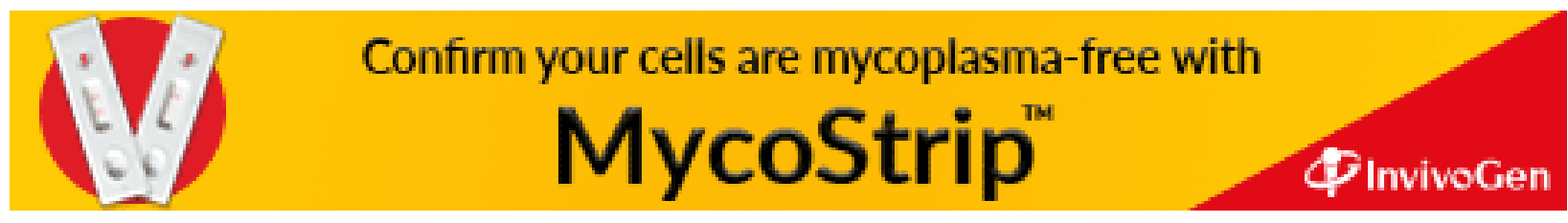

